\title{
The Rif and California: Environmental Violence in the Era of New Cannabis Markets
}

\author{
Kenza Afsahi
}

\begin{abstract}
This chapter explores the different forms of environmental violence practised against humans and nature (including the cannabis plant) in a context of intensive cannabis cultivation. In particular, it examines the effects of the industrial farming of cannabis since the 196 os on water, land, forests, animals and farmers. It also investigates the exploitation of the labour force, which has comprised vulnerable populations, especially women and landless agricultural workers since Rifian agriculture was first integrated into colonial capitalism in Morocco. While this study focuses on the Moroccan territory, the situation presented is by no means unique at the global level. The phenomenon can be seen developing both within a framework of prohibition and when legal and illegal actors adopt a capitalist system of exploitation, as is the case in California.
\end{abstract}

The cannabis industry has undergone numerous reconfigurations in recent years. $^{2}$ It is now a multifaceted sector in terms of the products it offers, the

1 I would like to thank Khalid Mouna for his comments and suggestions on an earlier version of this text and also Najib Akesbi for giving me access to his work on Moroccan agriculture. I am also grateful to Abdellatif Adebib and Marta Jonville for our exchanges and for always being on hand when I needed them. My thanks go also to Anthony Silvaggio for sharing information on the environmental consequences of the cannabis industry in California.

2 This chapter examines industrial cannabis farming practices that pose an environmental risk. The many uses of cannabis for ecological purposes (rehabilitation of contaminated soils, replacement of forest products, etc.) are not examined here. It should be noted that the recreational and medicinal uses considered in this study are not the only potential uses of cannabis, which has also historically been used in the South for the manufacture of environmentally friendly products in domains such as food, textiles and cosmetics. However, these products, whether for commercial or family use, have been replaced by synthetic fabrics and plastic products, whose production and consumption are harmful to the environment. Significantly, cannabis-based products have made a recent comeback in the cannabis markets

(C) KENZA AFSAHI, 2020 | DOI:10.1163/9789004440494_012

This is an open access chapter distributed under the terms of the CC-BY-NC 4.o licenßenza Afsahi - 9789004440494 Downloaded from Brill.com04/26/2023 01:28:05PM 
large number of cannabis-producing countries involved, the mass of producers with different know-how, the many plant varieties grown and the very different qualities of cannabis weed, resin, oil and other preparations. The words used to refer to cannabis also tell their own story (Afsahi, 2017a). The past decade in particular has seen significant changes in the cultivation techniques used in European and North American countries, where cannabis cultivation has increased with the emergence of new ways of disseminating know-how, online seed outlets and shops selling indoor growing equipment to the public. These factors have all contributed to the diversification of products available. The increased acreage given over to cannabis and the selection processes it has been subject to (particularly in terms of different types of crosses) have influenced the genetics and biological characteristics of the original plant (to boost productivity and/or THC levels). The result has been a cultivated plant (Gerber, 2018) that has sustained uncontrolled hybridisation over decades of prohibition (Afsahi, 2017b).

At the same time, environmental change has accelerated since the 1960 os as a consequence of intensive cannabis farming and its adoption of industrial agricultural practices. In the 196os, agro-export models, driven by an increased demand for cannabis, led to intensive farming in the South and even to monoculture in some areas. The 1970s were marked by tolerance in regard to cannabis in the United States (US) and Morocco. This trend was to shift for the US a decade later with the criminalisation of cannabis cultivation and use (Corva, 2014). There was a considerable expansion in cannabis-growing acreage in Morocco in the 1980 os, due to a rising European demand for hashish (cannabis resin) and declining production in Lebanon and Afghanistan. The 199os saw California become the first US state to legalise cannabis for medicinal use (Corva, 2014; Silvaggio, 2018a and 2018b). At the same time, Morocco was experiencing episodic crackdowns on growers and the destruction of cannabis fields in response to international pressure, which, perversely, had the effect of intensifying cannabis cultivation in the country. Morocco's prohibition policy continued into the first decade of the new millennium. In 2012, meanwhile, Colorado and Washington became the first US states to legalise cannabis for recreational use following a referendum in each state.

Over the last decade, industrialised countries have seen the emergence of an industrial agriculture phenomenon in both indoor and outdoor cultivation in response to new cannabis markets. This expansion is, however, having the

of industrialised countries, where many companies are now manufacturing cannabis-based foods and cosmetics. 
same multiple environmental consequences as legal intensive agriculture, including soil depletion, loss of biodiversity, water pollution, increasing water scarcity and health risks to farmers and consumers. These impacts are very rarely measured or taken into account. From an economic and social point of view, these new, increasingly technology-driven cultivation practices (mechanisation, irrigation, chemicals, commodification of seeds) have created tensions between small farmers and large landowners, who have easy access to resources and a labour force made up of the most vulnerable populations, namely women, children and seasonal workers.

In rich countries, after decades of fighting to obtain the right to cultivate and consume cannabis, industrial groups both large and small are now fighting among themselves, each looking to invest in and exploit cannabis for its many possible uses in a variety of fields, including construction, textiles, food, pharmaceuticals and cosmetics. This 'green gold rush', which comes at a time of huge global environmental change, forces us to question the conditions of production, use and circulation of this plant, which can take many forms and from which many derivatives can be extracted.

Originating in central Asia, cannabis was introduced via waves of migration to the Middle East, Africa, Europe and finally the Americas. It is now grown just about everywhere on the planet and has adapted to diverse climatic conditions not just outdoors but also indoors, for example in warehouses, greenhouses and cupboards with artificial lights and soils.

In the case of the Rif region (Morocco), after the signing of the 1961 Single Convention on Narcotic Drugs and the subsequent increase in international demand for cannabis, the Moroccan authorities followed a logic of prohibition and repression in line with the international convention, while the farmers looked to intensify their cannabis cultivation to meet demand. Environmental questions, if they were considered at all, were secondary for both actors.

The environmental consequences of cannabis production have received very little attention from researchers of any discipline, and have scarcely been mobilised by the activists who have fought prohibition for decades. Nevertheless, the environmental argument has been put forward many times to show the benefits of cannabis (insulative, depolluting, etc.) and to moralise the market.

This study, which is part of an ongoing research project exploring the ecology of cannabis, is a reflection on the global cannabis economy and its current social, economic and environmental issues. It focuses on different forms of environmental violence against natural resources, humans and the cannabis plant, in a context of intensive cultivation. The concept of 'environmental violence', which originated in the field of environmental criminology (South 
and White, 2016), is understood here as violence against the natural environment, certain species (human and non-human) and the planet. This analytical framework takes into account not just social damage but also plant protection, the violence plants are subjected to and the environmental and health impacts of intensive crop farming. The environmental crimes considered here also extend beyond those that have been defined by law. This approach, which is rooted in the field of actor-network sociology (Latour, 1994), attaches importance to non-human objects as actors in their own right.

This chapter will set out some of the changes that are affecting forests, land, water and animals. It will examine a range of social, economic, political and cultural practices that reflect a different way of telling the story of nature, a notion that seems to be taking on new meaning for growers today. It will also look at the exploitation of the labour force, which has comprised vulnerable populations, especially women and landless agricultural workers ever since Rifian agriculture was first integrated into colonial capitalism in Morocco. While the study focuses on the Moroccan territory, the situation presented is by no means unique at the global level. The phenomenon can be seen developing both within a framework of prohibition, and when legal and illegal actors adopt a capitalist system of exploitation and try to find an alternative to this ultimately doomed situation. The experiences of Morocco and the US state of California have been drawn on here as fitting examples because their differentiated regulations regarding cannabis cultivation show that the mechanisms put in place for indoor and outdoor production limit the consideration of environmental issues.

While market dynamics mean the cannabis cultivation context is subject to rapid change, environmental change can only be observed over a long period of time. It is thus impossible to measure the effects of cannabis cultivation over the space of just a few years. Moreover, it is difficult to approach the problem of environmental crime in a now globalised market at the level of a single social group and a single space. This analysis therefore needed to take into account several different levels of scale (geographical, historical, etc.) and the wide range of actors involved (farmers in the South, growers in the North, legislators, etc.). It compares the practices of actors in the South (the Rif) and in the North (California) to reveal two conceptions of a relationship to the environment in two different legislative, economic and technical contexts. The study is based on observations and informal, semi-structured interviews carried out on a sample of diverse actors in Morocco (farmers, cooperatives, etc.) and a sample of workers who had participated in growing activities in industrialised countries. In the absence of technical indicators showing changes in the natural resources concerned, we sought to gain an understanding of environmental 
crime and the resulting injustices from social indicators and from stakeholders' accounts of conflicts or tensions relating to the sharing of resources (Blanchon, Moreau and Veyret, 2009). These data were supplemented by exchanges with American researchers and by documentary research on the environmental question as it related to cannabis cultivation in California.

The first part of this chapter examines how the link between the Rif farmers and their environment has evolved with the intensification of cannabis cultivation for hashish production. This over-exploitation has also impacted workers, particularly the most vulnerable, including women and landless agricultural workers. The second part of the chapter will attempt to show how environmental violence in the South has spread to industrialised countries.

People aren't interested in crop diversity any more. In our ancestors' time, there were walnut trees, fig tree, cherry trees, vines, everything all together, and the local kif ${ }^{3}$ [Morocco's traditional cannabis cultivar] was planted in small plots so that it didn't take over the place, our ancestors chose specific plots, the most fertile, land that was well prepared, it had to be flat ... they grew on terraces, mainly because it stabilised the soil, they even used the rocks, the stones they found on the plots, they kept the shape of the land, respected it, everything had a role, they planted trees when they needed to ... It was a love affair between human, earth and insect, they only touched the top 10 centimetres of soil because the fertile earth's right at the surface, because insects live in it, they're part of the system, but now with the tractors, they kill everything, there used to be butterflies and there was this really unique species of locust.

Rif farmer, interview 2019

As this Rif farmer indicated, Moroccans have had a close connection with cannabis (or kif) for centuries. They used it in food, medicine and religious rituals, as well as for technical and recreational purposes or simply to help them endure harsh labour conditions (Afsahi, 2017a). It would be grown in small quantities in gardens alongside traditional crops, either for domestic use or to sell at market.

3 In Morocco, 'kif' refers both to the plant itself and to a traditional preparation intended to be smoked, which is made up of a mixture of dried tobacco and cannabis. 
The French and Spanish protectorates $(1912-56)$ were to play a key role in changing the Moroccan populations' relationship with this plant and their environment. France appropriated fertile land in various regions of Morocco to develop industrial plantations (Pascon, 1977; Lazaret, 2009[1968]). In 1914, with a view to financing its administration through the Régie du Tabac et du Kif monopoly (a company controlled by the Paris-based investment bank Banque de Paris et des Pays-Bas), the French authorities developed and produced a manufactured kif, which they sold to local populations at a great profit. Between 1912 and 1954, the French protectorate issued a number of dahirs (decrees), which were modified over time in response to the context of international prohibition, to regulate the cultivation, sale and use of cannabis (Afsahi, 2011). The Spanish authorities divided their protectorate into three zones: a political administration zone (Tétouan), an economic zone with fertile land and access to a water reserve (around the Loukkos River in Larache), and what was considered a rebel zone, which was populated by tribes and managed according to local custom (Jbala and Rif) (Mouna, 2018). The Spanish authorities tolerated cannabis cultivation in their protectorate to win over the Berber tribes. They levied taxes on the kif produced, and because they did not have access to the useful agricultural areas of Morocco, they exploited the Rif woodlands for timber. Spain changed the status of Morocco's woodlands with its dahir of 1919, which ordered that the woodlands, which until then had been managed by local tribes and communities (jamaa), would henceforth be in the public domain and managed by the state. The Spanish authorities turned the country's traditional slash-and-burn agricultural system into one that was focused on the over-exploitation of large forests for timber (Grovel, 1996).

When Morocco gained its independence in 1956, cannabis cultivation was definitively banned, although it was still tolerated within a small area located between the communes of Ketama and Bab Berred in the central Rif region, considered Morocco's historical home of cannabis cultivation. The colonial legacy, the country's prohibition of cannabis under international pressure, and the increased demand for cannabis in the 196os all resulted in a further change in local populations' relationship to their environment. Prohibition created spaces for deviance. New tensions drove the farmers to brutally exploit the land. The government, which was trying to eradicate cannabis cultivation in the Rif, met with resistance from farmers and suspended its efforts.

The accelerated modernisation of cannabis production in the Rif and the development of a cannabis monoculture aimed largely at the export market has now become the norm. 'Monoculture' refers to an agricultural or forestry practice in which a single species is cultivated over a large area with intensive use of chemicals and no crop rotation. In the Rif, where the terrain is very 
rugged, monoculture involves small areas of land, sometimes even parcels of land, devoted to a single, aligned, standardised cannabis crop. This monoculture has reshaped the Rif landscape and replaced the former multi-crop landscape described below:

On our land, there was loubia (beans), dra (maize), all the vegetables, turnips, they didn't buy anything in the old days, there were fruits, a vine for zbibes (grapes), which they'd eat in the winter, figs, guergaa (nuts), everything, cherries, these were developed people, even those who had nothing had at least forty or fifty goats. Every house had its own milk, butter and honey.

Rif farmer, interview 2019

Between 1960 and 1975, Moroccan populations largely cleared the woodland areas in response to the state's attempts, prompted by the growth of cannabis cultivation, to demarcate them (Grovel, 1996). Privatising state-owned land, burning down the woodlands and waiting for the state's reaction before starting cultivation, came to resemble a game played between the farmers and the forestry authorities. The farmers' opinions on the impact of the Spanish protectorate were mixed. Some saw the arrival of the Spanish as marking the onset of an 'ecological disaster' due to the radical change in the population's relationship to the woodlands, while others saw it as a new rationalisation of space and source of income, as this farmer recounted:

The logging companies arrived, there was an upside to the Spanish being here, they didn't just chop down trees willy-nilly, they were organised, they built sawmills, they'd chop down the trees and then plant new ones, they provided people with a living, fed them, paid them on time, they weren't exploited [...] they couldn't survive, they never used to cut anything down, only old trees[...].

Rif farmer, interview 2019

The suppression of the jamaa's role in managing their own needs and rights concerning land and forests changed the relationship that they had to their livelihoods and needs. Local populations no longer allowed the land to rest from one year to the next to increase its fertility, but instead used fertilisers or moved crops into the forests to conceal them better or to take advantage of more humus-rich soil. Cannabis revenues improved the livelihoods of poor populations and created new needs. This new economy also led to the emergence both of a new poor population that was dependent on the cannabis 
market and of more powerful actors with access to transnational trafficking networks.

Although the laws imposed by the Spanish, and subsequently by the Moroccan state, stipulated that woodlands should be protected, they did not take into account local populations' traditional forestry practices, beliefs and intimate relationship with all living species. Nature was seen as independent of those who had inhabited and preserved it for centuries, and who would continue to use it and benefit from it.

During the 1980s and 199os, land exploitation intensified as cannabis cultivation was established in new areas, either by historical cannabis growers or through the introduction of techniques disseminated by returning farm workers (who would capitalise on periods of tolerance from the authorities). In the 199os, due to a lack of land and in response to tightened forestry controls, some farmers began to go in search of new arable land, particularly in the province of Taounate. In partnership with local producers, they rented land in the traditional growing areas and experimented with production processes that had been difficult to implement for topological reasons (fertilisers and pesticides, tractors, modern irrigation systems). These new farms, especially in Chefchaouen province, practised monoculture in large irrigated valleys. Cannabis cultivation thus increased from a few dozen hectares in the 1950s to more than 100,000 hectares in the early years of the twenty-first century and spread over the five provinces of Al Hoceima, Chefchaouen, Taounate, Tétouan and Larache (Afsahi, 2011).

The cannabis monoculture system was not peculiar to the Rif, however, but rather derived from the state-run agrarian system that had been developed for legal crops since the colonial period. This modern style of agriculture incorporated hydraulic systems (dams) and the development of pesticides and fertilisers. Hence, even though it was not known as an agricultural territory, the Rif was the second region in Morocco to use fertilisers (Akesbi, 2005). Throughout this period, a number of programmes were introduced across Morocco, encouraging mechanisation and the excessive monoculture of legal crops. The so-called 'agro-export' model of agricultural development that was adopted produced the same effects as it did everywhere else in the world-namely, food dependency, rural poverty and the destruction of natural resources-and for the same reasons. As a result, Moroccans today depend on international markets for their basic food supply (Akesbi, 2013).

In the Rif, the totality of the land owned has been used to the maximum extent possible for cannabis specialisation. Farmers have thus taken over the forests and communal lands, created tracks for transporting the hashish, dug wells, modified their dwellings and invested in tractors when the land has been 
flat enough. They have, completely illegally, created an agro-export system that is identical to that created by the state in other agricultural regions. This approach has not, however, prevented the state from prosecuting them, and thousands have had arrest warrants issued against them or been sent to prison.

This new order, which is based on capital accumulation and the mass exploitation of natural resources, has brought with it highly visible inequalities and social injustices (Stengers, 2009). The gap between a very rich minority and almost the entire impoverished population has led to a new phase of deforestation and fighting for natural resources, even within families. Family solidarity has thus given way to competition between family members (Mouna, 2010) and all that this implies in terms of parcelling out land with increasingly reduced surface areas. As the area for cannabis cultivation has expanded beyond the historical growing area, there has been a rationalisation of both the territory and the lands used for cultivation, which are now characterised by increasingly rectilinear forms and controlled with modern production methods. The fact that this land is entirely given over to cannabis plantations has created ecological simplifications (Tsing, 2015) and reduced biodiversity in the Rif. Crop diversity, which used to limit both nature-related and commercial risks, has disappeared along with market gardens, residential gardens, fruit trees (except olive trees), some traditional livestock and some wild animals, such as monkeys and wolves, as this farmer from the historical cultivation area recounted:

There used to be a lot of animals here, all kinds of insects, butterflies I've never seen anywhere else, grey, multicoloured, birds, a huge variety of native birds, you'd never see them when you came down from high up in the mountains, in the cedars, there used to be wolves (there still are some but they're rare), wild boars, you still see a few, because they need the forest to hide in, stags in the zone, in the Spanish zone on the Tétouan side, for hunting. There used to be hyenas, my father told me. The last panther was killed in the mountains in the 5os by a Spanish officer, a white panther with black spots. You still see hedgehogs, and snakes, there used to be different kinds of snakes, my grandfather raised a snake in his house that ate mice ... my grandfather gave it eggs, he raised it, it used to be in the house, it wasn't poisonous or anything, it was like a guard dog.

Rif farmer, interview 2019

The animals that used to like eating the cannabis residues or seeds (e.g. roosters) are now tied up to prevent them from venturing into the fields. With the loss of traditional family farming, farmers are increasingly dependent on 
markets for food. Nature has thus been subordinated and commodified by humans for greater economic profitability with no concern for the environmental consequences (Petel, 2018).

While the woodland areas have been one of the battlegrounds for control for the Rifian populations involved in cannabis cultivation, water resources have also become increasingly problematic. Today, this poses a real challenge for Rifian populations, given the substantial pressure on groundwater and surface water for agricultural use. Throughout Morocco, with recurrent droughts, farmers are now dependent on irregular rainfall. At the beginning of the twentieth century, droughts in Morocco occurred only once every eleven years. By the 1960s, this had increased to once every seven years, and by the 199os there was a drought every two years. In 1999 and 20oo, the country recorded two consecutive years of drought for the first time (Akesbi, 2014). These droughts have led to pressure on the woodland environment, pasturelands and water tables, whose reserves are declining. New patterns of water use have emerged that are no longer characterised by the sharing of water resources, but by conflicts between small farmers and large landowners, who can afford to dig wells and build reservoirs.

Moreover, while the Rif is the biggest user of fertilisers and pesticides in Morocco, water pollution resulting from the intensive use of these substances in cannabis cultivation has never been measured in the region. This situation brings us back to the question of environmental justice. Regarding water as a shared social and cultural good is thought to lead, in a context of no state control, to continuing environmental inequality between growers in terms of their access to and use of water (Belaidi, 2010).

Ever since the intensification of cannabis production began in the Rif, the question of resources has thus been a constant issue. It has created a divide between those who own the fertile soils, agricultural acreage, water sources and labour force needed for cannabis cultivation and production, and those who do not. Even within the same territory, the intensification of crop production has generated considerable wealth for some villages (those with large tracts of irrigable land where mechanisation is possible) and none for others (those with only small parcelled acreages, usually situated at high altitudes). This has created tensions and has even led to instability.

Profound ecological changes have altered not just these populations' way of life but also their conceptions of the land, forests, water and farming techniques and practices. Their stories about natural resources and animals have also changed. For example, many of the farmers argued that the more fertiliser and pesticides they used, the better the soil would be. As Salvador (2011) pointed out, historically, workers in industries that have caused significant 
environmental damage, such as the chemical industry, have tended to defend their production methods and those of polluting enterprises more generally. Their jobs took precedence over their health and that of their descendants. The author thus shows that the environmental question is closely linked to the social dimension.

Some connections with nature have nevertheless remained for Rifian populations. Although the farmers have cleared much of the woodland area, most have continued to consider olive trees as sacred. They are the only fruit trees that can be seen still standing in the cannabis fields. Furthermore, the farmers of Ketama look on the cedar forests of Mount Tidirhine as their inviolable heritage and have protected them from timber traffickers.

\subsection{Women and Seasonal Workers: Exploitation of the Labour Force}

Since the 196os, Rif farmers, in addition to exploiting natural resources in this context of intensified cannabis cultivation and hashish production, have increased their use of family and seasonal labour. Because the rugged terrain has prevented the mechanisation of some cannabis farms, thousands of workers with either precarious status (paid workers or servants) or invisible status (undocumented workers) are used at all stages of cultivation and production, namely sowing, weeding, thinning out, harvesting, drying and storage, sieving, pressing and selling (Afsahi, 2011). These workers, who are employed largely because of their vulnerability (women, seasonal agricultural workers, children), perform the most gruelling tasks in the cultivation process. The women are generally involved in the weeding, thinning out (removal of male plants) and harvesting, rather than the more technical activities such as sowing and production. Neither do they take part in the more visible activities, such as transportation and retail, but are instead used to free up the men for these tasks (Afsahi, 2015). The low visibility of women conceals a gender division in domestic roles as well as certain internal selection mechanisms (Frau, 2012) and many inequalities. Some of the tasks they are given are incorporated within domestic work more broadly, which increases their invisibility (Krinsky and Simonet, 2012). In addition to their domestic tasks, women are given the role of looking after the livestock and the children, and fetching firewood and water. They are also responsible for preparing meals for the seasonal farm workers.

This use of female labour helps to legitimise cannabis cultivation as a family activity, which to some extent minimises the risks for the men involved and shields them from being arrested (Afsahi, 2015). Very occasionally, women replace men in the retail task. This only happens when the men are in prison or, in the case of some fishing villages, out at sea for long periods. Thus, the women are emancipated by their husbands' absence (Afsahi, 2015). 
Women are oppressed in many ways. As workers, daughters, mothers and wives they are burdened with many tasks and have little autonomy. They have a considerable, often unpaid workload, and they receive no social recognition or personal income. The women and men seem to have some kind of implicit social contract, which provides that - in exchange for their work in the fieldsthe women's standard of living or domestic comfort increases albeit they will not receive any pay.

Growers who have devoted increasing amounts of land to cannabis cultivation and begun to produce the end product themselves have supplemented family labour with a large number of agricultural workers (Aziza, 1994; Maurer, 1968). These workers come from all over Morocco, but particularly from the communes bordering the historical cultivation area of the central Rif.

Hence, every year, at the start of the cannabis cultivation period, workers from different towns and regions converge on the Rif in the certainty they will find work. Seasonal migration from some urban areas is common, notably from Meknes and Fez as well as some more distant cities such as Kenitra. The agricultural workers negotiate their daily wage with the chief of each tribe according to seniority, know-how and supply and demand. A distinction is made between multiskilled workers, who are able to help with domestic or agricultural tasks or even with road construction and marking, and specialist workers, who work solely on transforming the cannabis plants into resin. These latter workers are the more in-demand of the two types, especially in the new cultivation areas that have not yet acquired this specific know-how. Recruitment is based on trust. An employer will ask a good worker to come back the following year, and a good worker is able to recommend a new worker. Workers are also recruited at markets or in the countryside, where foreign workers are highly visible because they can be seen travelling with their personal belongings across territories according to the seasonal harvesting cycles, seeking out any contracts employers are willing to offer them. Despite being paid, seasonal agricultural workers constitute precarious and invisible labour. Very rarely do they have a voice or the right to participate in a decision (Mouna, 2010).

\section{Internationalisation of Cannabis Cultivation and Resource Exploitation}

Today, industrialised countries are cannabis producers in both legal and illegal contexts. It is important to stress here that environmental crime is defined as an 'act' or 'omission' that harms human beings, the environment and/ 
or animals, regardless of its legality or illegality (Manirabona, 2016). Given the globalisation of the cannabis market, it is essential for harmful impacts, whether legal or illegal, to be considered in an international context. In a study of the intermediate actors and mediators involved in the production and circulation of both cannabis seeds and knowledge between Morocco and Holland, the present chapter's author saw how highly localised actors (in the Rif) were linked to highly mobile actors (in Holland) (Afsahi, 2017a and 2017b).

Morocco and California have been selected as cases studies for the present study not so much to show the interdependence of the two areas as to show how environmental crime today transcends state borders in terms of cannabis cultivation practices and the exploitation of natural and human resources, a phenomenon that has remained at the margins of the concerns of various actors in the cannabis industry.

After decades of campaigning by user and patient associations, as well as the high-profile activists (Michka, Miya Jansen, etc.) who have popularised knowledge about cannabis and influenced public and consumer opinion (consumers increasingly prefer local products), new legislation in different national contexts (the US, Canada, the EU, etc.) has led to new forms of the marketisation of cannabis. Countries are attempting to create regulated markets at every stage, from cultivation through to consumption, with the aims of reducing or even replacing the illegal market, adding economic value to the product through taxation, and protecting human health. As a result, the market is booming, and many industrialists are looking to invest in and exploit cannabis in a number of different sectors, including construction, textiles, food, medicine, cosmetics and recreation. As such, they are in competition with cannabis producers in the South.

These industrialised countries are beginning to think about the positive (risk reduction, economic contribution of new markets, weakening of the black market) and negative (increase in consumption by young people) effects of these new markets in the contexts of prohibition and legalisation. However, very few human and social science studies have examined the environmental consequences of industrialisation and the growth of the cannabis market in industrialised countries. Moreover, the arguments in favour of legalisation and the issues at stake have focused on economic, social and public health benefits without taking into account environmental damage. The only studies to have addressed the environmental question have been Silvaggio's (2018a and 2018b) studies of cannabis farming in Humboldt, Mendocino, and Trinity Counties (an area in Northern California known as the Emerald Triangle), Bauer and coauthor's (2015) study of water demand for cannabis irrigation and the impacts of water diversion, Mills's (2012) study of energy consumption in indoor 
cannabis cultivation in the US and August's (2013) study of the role of women in the cannabis industry.

In California, cannabis was introduced most notably by the hippy communities of the 196os and 1970s. The local industry subsequently developed through an underground network of producers, consumers and dealers (Rendon, 2012). Since the 1980s, California has been known for producing some of the best cannabis products in the world. Initially, cannabis cultivation had little impact on the environment in California. However, after decades of logging and poor land management, and following the legalisation of cannabis for medical use in 1996, California entered a new phase in its industrialisation of cannabis. Not only did cultivation increase from 20 or 30 plants per farm to plantations containing hundreds or even thousands of cannabis plants, with all the associated harmful consequences for the physical environment, this new agriculture created a real need for workers who would cultivate, harvest and sell the cannabis. Local workers were soon joined by young, international, seasonal workers. This over-exploitation of the natural environment has also been facilitated by a number of legal grey areas. Most growers in the region conceal their crops or say that they are intended for medical use or for dispensaries licensed since 2016. In reality, only a tiny fraction of production is destined for this legal market. The rest is channelled into the country's black market, an industry with an estimated value that varies considerably but that is rarely reported at less than USD 10 billion (Silvaggio, 2018a and 2018b).

Indoor cannabis cultivation in California, which emerged in response to a crackdown on outdoor cannabis cultivation in the 1980s, has also had an impact on the environment (Corva, 2014). Domestic cannabis cultivation, which has been developed in most industrialised countries to avoid control measures and unfavourable climatic conditions, uses a highly controlled environment for growing (lamps and irrigation). It has also introduced many new techniques to influence the growth cycle of cannabis, for example by crossing multiple varieties to create new varieties with higher THC levels, increased yields or new tastes and effects. In California, indoor cultivation has created a production environment that is suited to the hybridisation of different varieties of cannabis plants with specific characteristics, such as a shorter growing time, higher potency or a particular smell, making Californian cannabis among the most famous varieties in the world (Silvaggio, 2018a and 2018b).

However, these growers have impacted the local environment. Indoor production, whether small- or large-scale, requires large amounts of fossil energy to power generators, lighting and advanced climate control systems. Mills (2012) observed that the emerging industry of indoor cannabis cultivation (both legal and illegal) uses energy-intensive control processes. He estimated 
that cannabis cultivation accounted for 1 per cent of national electricity consumption, which was equivalent to USD 6 billion in the case of the US. An average kilogram of end product is associated with 4,6oo $\mathrm{kg}$ of carbon dioxide emissions. Indoor cannabis cultivation is believed to account for 3 per cent of energy consumption in the state of California (Silvaggio, 2018a and 2018b). Several other US states (including Colorado and Alaska) - along with Washington, D.C.- - have legalised cannabis production, and thus encouraged indoor cannabis cultivation. Hood (2018) shows that in the state of Colorado, for example, where the majority of legal cannabis is produced indoors, electricity consumption has put a strain on power grids, with cannabis cultivation accounting for more than 4 per cent of Denver's total electricity consumption. Moreover, Ward (2018) reports that the packaging for one gram of cannabis concentrate can weigh up to 30 times more than the product itself.

The scientific literature in the field of environmental crime has shown that environmental criminals tend to target areas where legislation is most lax. Researchers have noted that environmental crime has been exported from developed to developing countries (South, 1998). This can certainly be seen in the period following the intensification of cannabis cultivation in the South in response to increased demand for cannabis in industrialised countries from the 1960s onwards. However, today, prohibition and new regulations accompanied by the rise in cannabis cultivation appear to be producing relatively similar levels of environmental damage in both developed and developing countries, albeit environmental inequalities remain (Chancel, 2017).

Countries in the South are more exposed to economic and social inequalities, which lead to environmental inequalities. These are defined as unequal access to natural resources and unequal exposure to environmental harm and risks (Hache, 2013). The populations most affected by the consequences of environmental crimes are the poorest, and often it is the wealthiest who are the agents of these crimes (Hache, 2013). Similarly, at a local level, populations with the lowest incomes are the most exposed to pollution phenomena or environmental risks (Hache, 2013). According to Chantal (2017), inequalities are cumulative because economic and social inequalities also translate into environmental inequalities.

At the global level, the cannabis cultivation context is characterised by inequalities in terms of access both to the market and to natural resources for the most vulnerable populations. This is especially true for farmers in the South, who face food security difficulties as well as technical challenges and violence when it comes to accessing land and water resources. The direct exploitation of resources by colonisers, followed by the indirect exploitation of resources after independence by the rich, continues to characterise the cannabis market. 
The cannabis market is moving towards an increasingly unequal exchange between industrialised countries, which have evolved in terms of their regulations, and the South, which remains at the margins of this development.

Hence, the Rif is no longer able to rely on its scorching sun to enhance the reputation of Moroccan hashish and compete with the new European cannabis market. For at least a decade now, hybrid seeds and new cultivation and extraction techniques have been imported from industrialised countries. Hybrids produce two to three times higher yields per hectare than kif, and greater psychotropic effects than traditional Moroccan hashish (Chouvy and Afsahi, 2014). Most farmers have thus replaced their local, traditional cannabis varieties to diversify their supply. However, these hybrids are even greedier when it comes to fertilisers, pesticides, water and labour, further deteriorating an environment already weakened by decades of intensive cannabis cultivation for industrial-scale production. As ideas and knowledge have circulated between legal and illegal spheres and between industrialised countries and Morocco (Afsahi, 2017b), Morocco has adopted an increasingly technical, hyper-intensive European agricultural model that involves large quantities of fertilisers, pesticides, greenhouses, pollinators, hybrid seeds, lamps, and new hashish extraction techniques. Many foreigners have also settled in the Rif to produce locally, taking advantage of the sunshine and very cheap labour. According to judicial sources, violent crimes have been committed in Issaguen in connection with conflicts over water usage rights. This is a new development in an area known for its absence of violence.

The Rifians' connections with kif have changed with these new practices. They now have new, more distant connections with the new hybrid varieties that have been introduced. This intensification of cultivation has also snuffed out the ecological stories and cultural and religious practices that the early kif growers in Morocco drew on to give meaning to their culture and their space. As is the case with the illegal trafficking of wild species (fauna and flora) (Bernard, 2016), cannabis is today subject to risks related to biodiversity, the health of users and growers, the protection of original varieties and the plant's sustainability as a species. The circulation of hybrid varieties in Morocco is facilitated by a legislative vacuum around cannabis seeds and the ease with which actors in the seeds market can move between the two Mediterranean coasts (see Afsahi, 2017b). At the local level, the wealthiest growers, who are those most involved in the seeds circuit, have invested in damming water sources (reservoirs), which are essential for the cultivation of hybrid cannabis varieties. The specially created water police unit in Morocco turns a blind eye to the rapid degradation of water reserves. In an article on groundwater governance policy in Morocco, Del Vecchio and Mayaux (2017) show how the use of 
groundwater, unlike the use of an alternative method of surface water management that is part of a classic planning policy pertaining to the state's 'hydraulic mission', reveals a liberal state policy that encourages Moroccan farmers' entrepreneurial spirit. Cannabis growers have been able to capitalise on this. Some actors in the cannabis economy even control every stage of cannabis cultivation and retail, including the short-term management of natural resources, and they know how to react to global changes in the cannabis market.

In contrast to California, the debate on the legalisation of cannabis for medicinal and industrial use in Morocco has been subject to party politics. Legalisation has been rejected by cannabis growers, who do not see the economic benefits of such a change. Some are afraid of being excluded from a legal market, particularly the pharmaceutical market, whose networks and circuits they do not control. They argue that a legislative change would primarily benefit other agricultural regions that are better equipped with natural resources (Mouna and Afsahi, 2015).

\subsection{Women and Vulnerable Workers in the New Cannabis Industry}

Ultimately, in both worlds (developed and developing), prohibition and new regulations seem to be harming the most vulnerable populations, namely agricultural workers, especially small farmers and women. The effects of regulation (registration fees and taxes) in California, for example, have pushed out the small farmers who produce sustainably and encouraged an increase in large-scale plantations (Silvaggio, 2018a and 2018b; Allen, 2018). With regard to the vulnerable workers employed in the sector, an ethnographic study carried out between 2010 and 2012 (August, 2013) in the Emerald Triangle showed a male dominance of the sector, both physically and in terms of decisionmaking. Women were thus relegated to subordinate roles. The 'heavy' work was assigned to men, and thinning out was usually assigned to women. A number of participants recounted how men dominated the sector and how they were keen to maintain the division of labour and the norms that governed this environment. Working conditions increased the women's vulnerability, a fact that resonates with the labour market in this sector more broadly. The author of this study explained that the women were fully aware that the nature of the work also exposed them to sexual harassment.

However, since the legalisation of cannabis for recreational use in California on 1 January 2018, some new trends regarding the place of women in the cannabis industry have emerged. While Anderson and Kavanaugh (2018) have highlighted the widespread perception of strong gender inequalities in the production and distribution of drugs, they have also shown how women have taken up a new place in the production of cannabis derivatives through 
activities generally considered to be gendered. Hence, new businesses specialising in bakery, confectionery and other edible products have appeared since the legalisation came into force. These new uses of cannabis, which are seen as feminine by men (who are more interested in the transactional side of the business), give women an important place in the economic chain formed by the legal sale of cannabis in some US states. This gender bias has allowed many women to enter the cannabis market and has practically created the idea of 'female domination', as reflected in a US magazine's proposition: 'Will a plant named Mary Jane smash the drug market patriarchy?' Some women workers have also formed growers' collectives. It is worth noting that this reaction is not specific to California. An increasing number of cannabis events are hosting special sessions dedicated to women in the cannabis industry.

Moreover, the demand for labour-whether female, local, immigrant or young seasonal, including workers from Europe-has been growing in recent years, particularly since the legalisation of cannabis. There are two types of farms in the cannabis industry. One is made up of open, seasonal farms, and the other of closed 'factories' that continuously produce indoors. The labour force on farms comprises mainly students or 'travellers', while the labour force in the 'factories' is mainly made up of immigrant populations, particularly from Latin American and Mexican communities.

One young French woman recounted her experience in the cannabis plantations of California in 2018:

We were on a small plantation, $45^{\circ}$ plants (two greenhouses), in the Californian backwater, the middle of nowhere. The cannabis was grown for medical use, so the owners of the place had to use organic farming methods, no chemicals. [...] I naively thought this was what happened right across the industry [...] but cannabis farming is an ecological disaster in California the same as it is anywhere else. The owners, they had a few plantations, put us in charge of the Copperhead one, there were two of us, isolated from everyone else. The nearest village was an hour's drive away, and that included twenty minutes along a dirt track. We could smell the plants half a mile before we got there. My job on the farm was watering the plants, by hand, one by one, two and a half hours a day, sprinklers weren't allowed. In the greenhouses, the temperature could reach $50^{\circ}$. So I'd go in with no clothes on every morning to take care of the plants, water them, take off the dead leaves, talk to them, stroke them. We formed a sensual bond really. It was an exchange of good working practices. I took care of the plants and they took care of me. They'd leave some resin on my skin, which relieved my aches and pains. Day in day 
out, I sweated under those greenhouses, I meditated to the sound of the water, breathed in their smell. I was immersed in it from head to foot. And I wasn't the only one who benefited. A whole load of animals of all kinds came in to drink the water and munch on the plants. Birds, rodents, snakes, chattering squirrels, spiders, insects, they were all there with me. Sometimes I saw deer, and bobcats also venture into the area. Since legalisation though, these small farms have been disappearing. They're being replaced by large farms that privatise the seeds, like they do in traditional agriculture. We're not allowed to make a living now from doing what we depend on for our livelihoods.

Former worker in California, interview 2019

\section{4}

\section{Conclusion}

Changes in cannabis regulation are intended to control cultural, environmental and social justice abuses, but the cannabis market currently has relatively few economic models that promote justice, respect for the environment and equity between South and North and rich and poor. The intensification of cannabis cultivation has further deepened territorial and social inequalities at a number of levels between the traditional growing countries, which have supplied the international market with cannabis for decades, and the industrialised countries, which have switched from importing cannabis to now specialising in cannabis cultivation and adjusting their legislation accordingly.

Environmental inequalities, which crystallise the many local conflicts over natural resources and the exploitation of labour forces, can be observed in different spaces around the world. These new cannabis-related environmental inequalities associated with access to natural resources (Hache, 2013) reveal the challenges of accessing the cannabis market and of the current cannabis economy.

In Southern countries, as exemplified by the Rif, large landowners exploit their labour force, which is made up of landless agricultural workers, women, and farmers. However, this is also true of California. Both these territories have suffered at the hands of humans, with their machinery, agricultural technology, over-exploitation, fertilisers, pesticides, and so on.

Environmental changes in the context of cannabis cultivation show us how the process of destruction has accelerated in recent years and echoes a more global and globalised ecological crisis. The environmental impact from regulatory vacuums and prohibition (Silvaggio, 2018a and 2008b; Corva, 2014) has been compounded by new legislation, which has turned a deaf ear to 
prominent voices calling for environmental sustainability. Instead, it has focused on the millions or even billions of dollars that the cannabis industry has generated for large corporations, which have in turn been able to influence state administrations and regulatory advisory boards (Silvaggio, 2018a and 2008b), and push for less stringent environmental policies and regulations.

New legalisation could thus risk intensifying the phenomenon of growing crops under glass, both indoors and outdoors, to accommodate the expanding market (Silvaggio, 2018a and 2008b). There is currently a lack of empirical data on the environmental costs associated with cannabis cultivation. However, it is clear that, given the economic importance of cannabis cultivation, it will have a significant impact on water, flora and fauna (Allen, 2018). We therefore need to mobilise our collective imagination to ensure that the solutions to cannabis prohibition - in other words, the new cannabis economies - do not follow the school of thought that espouses unfettered competition.

\section{References}

Afsahi, K. (2017a) 'La construction socio-économique du cannabis au Maroc : le kif comme produit traditionnel, produit manufacturé et produit de contrebande', Tempo Social, 29(2) (Dossier 'Drogas e sociedade em uma perspectiva comparada'), pp. 99-114.

Afsahi, K. (2017b) 'Ketama et Amsterdam : passeurs et développeurs de savoirs dans la production de haschich', Autrepart, 2(82) (Dossier 'Circulation des savoirs et espaces d'apprentissage au Sud'), pp. 161-177.

Afsahi, K. (2015) 'Pas de culture de cannabis sans les femmes. Le cas du Rif au Maroc', Déviance et Société, 1(39), pp. 73-97.

Afsahi, K. (2011) 'Cannabis cultivation pratices in the Moroccan Rif', in T. Decorte, G. Potter and M. Bouchard (eds), World Wide Weed. Global Trends in Cannabis Cultivation and its Control (Farnham: Ashgate), pp. 9o-114.

Akesbi, N. (2014). Le Maghreb face aux nouveaux enjeux mondiaux, Les investissements verts dans l'agriculture au Maroc (Paris-Bruxelles : IFRI, Programme Moyen-OrientMaghreb).

Akesbi, N. (2013) L'Agriculture marocaine entre les contraintes de la dépendance alimentaire et les exigences de la régulation sociale. Maghreb Machrek, 1(215), pp. 31-56.

Akesbi, N. (2005) 'Évolution et perspectives de l'agriculture marocaine', Rapport, groupe thématique 'Croissance économique et développement humain', 50 ans de développement humain et perspectives 2025, Cinquantenaire de l'Indépendance du Royaume du Maroc, Rabat. 
Allen, H. (2018) 'The Transition to Legal Cannabis', 14th Annual Schaub Memorial Lecture, Humboldt State University, March 26.

Anderson, T.L. and P.R. Kavanaugh (2018) 'Women's Evolving in Drug Trafficking in the United States: New Conceptualizations Needed for 21st-Century Markets' Contemporary Drug Problems, 44(4), pp. 339-355. DOI: o.1177/oog1450917735111.

August, K. (2013) 'Women in the marijuana industry', Humboldt Journal of Social Relations, 35, pp. 89-103.

Aziza, M. (1994) Le Rif sous le protectorat espagnol (1912-1956) marginalisation et changements sociaux: naissance du salariat, $\mathrm{PhD}$ thesis, Université Paris 8.

Bauer, S., J. Olson, A. Cockrill, M. van Hattem, L. Miller, M. Tauzer et al. (2015) 'Impacts of Surface Water Diversions for Marijuana Cultivation on Aquatic Habitat in Four Northwestern California Watersheds'. PLoS ONE, 1O(9), DOI: 10.1371/journal. pone.0120016.

Belaidi, N. (2010) '19. L'eau, un enjeu de justice environnementale', in G. SchneierMadanes (ed) L'eau mondialisée. La gouvernance en question (Paris: La Découverte), pp. $353-365$.

Bernard, T. (2016) 'La lutte contre le commerce illégal d'espèces sauvages', Criminologie, 49(2), pp. 71-93.

Blanchon, D., S. Moreau and Y. Veyret (2009), 'Comprendre et construire la justice environnementale', Annales de géographie, 1(665-666), pp. 35-6o.

Chancel, L. (2017) Une exposition inégale aux risques. Insoutenables inégalités: pour une justice sociale et environnementale (Paris: Les petits matins).

Chouvy, P.A. and K. Afsahi (2014) 'Hashich revival in Morocco', International Journal of Drug Policy, 25(3), pp. 416-423.

Corva, D. (2014) 'Requiem for a CAMP: the life and death of a domestic U.S. drug war institution', International Journal of Drug Policy. 25(1), pp. 71-80.

Del Vecchio, K. and P.-L. Mayaux (2017) 'Gouverner les eaux souterraines au Maroc. L'État en aménageur libéral', Gouvernement et Action Publique, 1(6), pp. 107-130.

Gerber, S. (2018) 'Les plantes cultivées cachent-elles la forêt?' in Q. Hiernaux and B. Timmermans (eds) Philosophie du végétal (Paris : Vrin).

Grovel, R. (1996) 'La préservation des forêts du Rif centro-occidental : un enjeu de développement de la montagne rifaine', Revue de Géographie Alpine, 4, pp. 75-94.

Frau, C. (2012) Agir sur un marché contesté: une sociologie du groupe professionnel des débitants de tabac, PhD thesis in political science, Université Paris I.

Hache, E. (2013) 'Justice environnementale, ici et là-bas', Contretemps, Revue de critique communiste, https://www.contretemps.eu/justice-environnementale-ici-et-la-bas/ (accessed on 13 May 2020).

Krinsky, J. and M. Simonet (2012) 'La servitude et le volontaire : les usages politiques du travail invisible dans les parcs de la ville de New York', Sociétés contemporaines, 3(87), pp. 49-74, DOI: 10.3917/soco.o87.0049. 
Latour, B. (1994) Changer la société, refaire de la sociologie (Paris: La Découverte).

Lazaret, G. (2009 [1968]) Les exploitations agricoles traditionnelles et modernes au Maroc dans les années 6o. Le tableau du Maroc du nord-ouest (Rabat: Publications FAO-Projet Sebou).

Manirabona, A.M. (2016) 'La criminalité environnementale transnationale : aux grands maux, les grands remèdes ?', Criminologie, 47(2), pp. 153-178.

Manirabona, A.M. and K. Koutouki (2016) 'Introduction : la criminalité environnementale'. Criminologie, 49(2), pp. $5^{-14}$.

Maurer, G. (1968) 'Les paysans du Haut Rif central', Revue de géographies marocaines, 14, pp. 3-70.

Mills, E., (2012) 'The Carbon Footprint of Indoor Cannabis Production', Energy Policy, 46 , pp. $5^{8-67 .}$

Mouna, K. (2018) L'identité de la marge. Approche anthropologique du Rif (Brussels: Peter Lang).

Mouna, K. (2010) Le bled du kif. Economie et pouvoir chez les Ketama du Rif (Paris: Ibis Press).

Mouna, K. and K. Afsahi (2015) 'Le cannabis au Maroc, du jeu politique local à la scène nationale' in B. Dupret (ed) Le Maroc au présent: d'une époque à l'autre, une société en mutation (Casablanca: Centre Jacques-Berque), pp. 191-204, https://books.openedition.org/cjb/1018.

Pascon, P. (1977) Le Haouz de Marrakech (Rabat: CURS and INAV; Paris: CNRS).

Petel, M. (2018) 'La nature: d'un objet d'appropriation à un sujet de droit. Réflexions pour un nouveau modèle de société', Revue interdisciplinaire d'études juridiques, 8o(1), pp. 207-239.

Rendon, J. (2012) Super-Charged: How Outlaws, Hippies, and Scientists Reinvented Marijuana (Portland: Timber Press).

Salvador, J. (2011) 'Prologue en forme d'interrogation sur le social et l'écologique', in J. Salvador (ed), La transition écologique (Toulouse: E RES), pp. 7-11.

Silvaggio, T. (2018a) The Environmental Impact of Cannabis Liberalization: Lessons from California, Paper prepared for the Cannabis Pracademic Summit, Quebec City, August 22.

Silvaggio, T. (2018b) Cannabis Agriculture in California: The Environmental Consequences of Prohibition, in Char Miller (ed) Where There's Smoke: The Environmental Science, Public Policy, and Politics of Marijuana (Lawrence: University of Kansas Press), pp. $13-28$.

South, N. (1998) 'Green Field for Criminology? A Proposal for a Perspective', Theoretical Criminology, 2(2), pp. 211-233.

South, N. and R. White (2016) 'L'émergence et l'avenir de la criminologie environnementale', Criminologie, 49(2), pp. 15-44. 
Stengers, I. (2009), Au temps des catastrophes. Résister à la barbarie qui vient (Paris: La Découverte, Les empêcheurs de penser en rond).

Tsing, L.A. (2015) The Mushroom at the End of the World: On the Possibility of Life in Capitalist Ruins (Princeton: Princeton University Press).

Ward, J.S. (2018) 'Marijuana packaging waste is the new water bottle', Rooster, November 26 , https://therooster.com/blog/wasteful-nature-marijuana-packaging-new-water-bottle (accessed on 15 August 2019). 